\title{
História, religião e religiosidade
}

\author{
Prof. Dr. Ivan Ap. Manoel
}

\begin{abstract}
RESUMO:
A abordagem das questões propostas pelo tema é uma tarefa que exige, preliminarmente, um estabelecimento de conceitos operacionais e normativos que permitam o entendimento razoavelmente seguro, ou menos problemático, desse universo.
\end{abstract}

Palavras-chave religião, religiosidade, história.

\begin{abstract}
:
The treatment of the proposed questions by the theme, it's a task which demands, first of all an establishment of operational and normative concepts which can allow an understanding reasonably secure, or less problematic of this universe.

Key-words: Religion, Religiosity, History.
\end{abstract}

\section{INTRODUÇÃO}

A abordagem das questões propostas pelo tema é uma tarefa que exige, preliminarmente, um estabelecimento de conceitos operacionais e normativos que permitam o entendimento razoavelmente seguro, ou menos problemático, desse universo.

Religião e religiosidade são produções humanas situadas na esfera da cultura, ou da superestrutura, se quiserem; são históricas, portanto, mas que por vezes são interpretadas como a - históricas e, além disso, se propõem elas mesmas, estabelecerem um conceito e uma filosofia da história.

A complicar ainda mais o trabalho, sabemos que são múltiplas e multifacetadas as conceituações existentes sobre religião, religiosidade e história, de modo que é necessário, digamos, desbastar um pouco esse terreno para que possamos transitar melhor por ele. 
O que podemos entender por história? Pergunta aparentemente despropositada após tantos séculos de estudos sobre a história humana.

Deixa, entretanto, de ser absurda quando se verifica que, no mundo ocidental, isto é, aquela parte da humanidade diretamente amoldada pelo eurocentrismo, são várias as interpretações elaboradas.

Entretanto, a multiplicidade de interpretações elaboradas no muno ocidental apresentam um traço de união, um elo ligando-as de algum modo. lluministas, marxistas, positivistas, enfim, as racionalidades européias da passagem do século XVIII para o XIX em diante, das quais derivaram outras vertentes, tais como historicismo, culturalismo, existencialismo, etc. todas elas estabeleceram uma interpretação da história lastreada na certeza de que ela é, foi e sempre será uma produção da racionalidade e da ação humana.

Em outros termos, a história humana é produto da ação humana, sem a interferência de nenhuma força transcendente, isto é, situada fora do muno físico; a história, portanto, seria sempre imanente, conseqüentemente sempre racional, inteligível, um processo explicável por métodos e procedimentos apropriados, um devir perfeitamente cognoscível e, em alguns casos, como no marxismo, previsível.

Sou tendente a concordar com as linhas gerais dessa forma de se conceber a história. Parece-me que, sem dúvida alguma, a história humana é um processo estritamente humano. Cabe, entretanto, perguntar: processo de quê?

Entendo que a história é o processo humano de sua autoconstrução, o longo caminho que trouxe o homem da condição de um gênero que se diferenciou dentro da ordem dos primatas até à nanotecnologia e explorações espaciais.

Uma objeção inicial a essa forma de se colocar o problema diz respeito à não evolução moral da humanidade que, não obstante a evolução científica e tecnológica continua a agir de modo semelhante no transcurso da história, cometendo os mesmos crimes e atrocidades, incluindo-se o genocídio, sofisticando-os conforme o elenco dos recursos tecnológicos disponíveis.

É exatamente nesse domínio que os conceitos racionalistas acabam por se distanciarem e se diferenciarem dos conceitos religiosos ou derivados das formas religiosas de se conceber a história.

106 ReVISTA de Cultura TEOLÓgICA - v. 15 - N. 59 - ABR/Jun 2007 
Por religião entendo o conjunto de doutrinas e práticas institucionalizadas, cujo objeto e objetivo é fazer a ponte de ligação entre o sagrado e o profano, o caminho de reaproximação entre criatura e criador, o Homem e Deus. Não por acaso, os sumos sacerdotes da maioria das igrejas, também são denominados Sumos Pontífices, os Supremos Construtores da Ponte Sagrada.

É evidente que essa conceituação se refere ao campo religioso monoteísta do mundo ocidental - não me atreveria adentrar sequer o Oriente Médio, por não conhecer a religião islâmica o suficiente, quanto mais o Extremo Oriente e as religiões africanas. Assim, me restrinjo ao cristianismo e alguns tópicos do Antigo Testamento, o que já não é pouca coisa.

No mundo ocidental, no Brasil, particularmente, o predomínio religioso se encontra concentrado nas igrejas cristãs, a Católica Romana, a Metodista, Presbiteriana, Batista, etc. e nas derivadas do "protestantismo histórico", vulgarmente denominadas "evangélicas", de caráter pentecostal algumas delas, como a Congregação Cristã no Brasil, e assim outras mais.

Essas igrejas se constituíram historicamente como o canal de manifestação da religiosidade; entretanto, devemos reconhecer que nem sempre a religiosidade se manifesta por meio de religiões institucionalizadas.

A religiosidade, na sua condição de característica exclusivamente humana, revela um atributo humano de busca do sagrado, sem especificar o que seja esse sagrado, tanto como fuga, quanto como explicação para o real vivido, ou ainda mesmo para negociações e entendimentos com a ou as divindades na procura de resoluções de problemas cotidianos. Esse atributo humano não está referido a nenhuma religião específica, e é um domínio mais pertinente aos antropólogos e psicanalistas do que ao historiador.

Por essa razão, as práticas da religiosidade, muitas vezes entendidas como bruxaria, feitiçaria, "espiritismo", nada mais são do que manifestações não institucionalizadas da religiosidade e exatamente por isso são sincréticas, livres e além de qualquer ortodoxia dominante.

A forte marca heterodoxa da religiosidade impede que se encontre nela elementos que permitam entender o diálogo existente entre as formas religiosas e as racionalistas de se conceber a história. Por exemplo, uma religiosidade popular que incorpore elementos cristãos e kardecistas, operará com dois conceitos distintos e excludentes de história, o retilinear e 
escatológico cristão, desenvolvido a partir de Santo Agostinho, e os ciclos incontáveis de recomeço da doutrina da reencarnação do kardecismo.

Desse modo, é imprescindível que nosso olhar se fixe no diálogo, áspero e contundente no mais das vezes, entre as igrejas cristãs institucionalizadas e os racionalismos.

A bem do andamento do nosso diálogo convém cautela em relação ao termo racionalismo e seu antônimo, irracionalismo. O seu emprego indiscriminado pode levar à conclusão de que as formas religiosas de pensar dispensam o uso da razão, o que seria um absurdo até do ponto de vista fisiológico. O que está em pauta é a afirmação de que a concepção religiosa da história, no nosso caso, a concepção cristão da história prescinde da ação e do pensamento humano, daí porque seria irracional.

Assim posto o problema, as questões são bem mais complicadas.

As religiões derivadas do cristianismo se sustentam em uma concepção da história que tem dois fundamentos, sendo o primeiro a noção de retilinearidade e de escatologia e o segundo a noção de história como processo progressivo. Entrelaçando essas duas noções está a concepção de ser a vontade humana o motor e a direcionadora da história.

Temos aí, portanto, uma filosofia da história: é um processo progressivo, que de um ponto inicial se desenvolverá até chegar a um final, e esse processo é conduzido exclusivamente pela vontade humana. Essa filosofia, ao estabelecer que o processo histórico é retilinear, se contrapunha frontalmente à idéia grega de histórica, concebida como uma circularidade, um eterno repetir-se sem fim e sem saída. A filosofia cristã da história "esticou a linha" da história.

Coube a Santo Agostinho a tarefa de "esticar a linha" criando, com isso, a "linha do tempo", até hoje empregada pelas escolas historiográficas e pela própria filosofia católica da história que é, concomitantemente, o alicerce da doutrina dessa religião. Sua escatologia somente terá sentido se o percurso da história humana for retilinear; melhor dizendo, sem a concepção de percurso retilíneo da história não haveria a escatologia católica.

Rigorosamente, não foi Santo Agostinho quem "inventou" a retilinearidade do movimento histórico. Essa idéia já estava na lógica dos textos sagrados do judaísmo, que o cristianismo veio a consolidar. 
Em Daniel, Isaías e outros profetas do Antigo Testamento, já estavam em germe ou explicitada, a concepção escatológica e teleológica da história, isto é, a idéia de início, transcurso linear e final da história em um futuro longínquo. Não havia, entretanto, explicitada a idéia de um futuro além da materialidade. Foi após São Paulo que os evangelistas Mateus, Marcos, Lucas e João, com o seu Apocalipse, introduziram a idéia de além, de eternidade que está nos fundamentos do Novo Testamento, portanto nos alicerces da doutrina das igrejas cristãs.

"Uma vez que, depois da partida de Jesus (já em Paulo) os interesses se deslocam para um além e se individualizam, passa-se a entender o aquém antes como lugar de decisão e provações das quais os crentes são salvos por intervenção de Deus que os transforma e os transfere para uma dimensão de além (o 'céu'), não se prometendo nenhuma salvação para o aquém mesmo."1

Nos profetas veterotestamentários, o texto indicava sim o apocalipse, o final dos tempos e a "vitória do Senhor", mas a idéia não era de uma solução de continuidade no processo histórico após esse evento, mas a idéia de fim do sofrimento do povo judeu, constantemente oprimido por invasões e dominações estrangeiras conforme se lê em Daniel e Isaías

"Alegrem-se o deserto e a terra seca, rejubile-se a estepe e floresça; como o narciso, cubra-se de flores, sim rejubilem-se com grande júbilo e exulte./Assim voltarão os que foram libertado por Javé, chegarão a Sião gritando de alegria, trazendo consigo uma alegria eterna: o gozo e a alegria os acompanharão, a dor e os gemido cessarão." ${ }^{2}$

"o fim das desgraças e do pecado, e o advento do Reino dos Santos, governado por um Filho de Homem, e o seu reino não passará."3

\footnotetext{
1 VORGRIMLER, H. Escatologia/Juízo. In, EICHER, Peter (dir.) Dicionário de conceitos fundamentais de Teologia, p. 230.

2 EDIÇÕES PAULINAS. A Bíblia de Jerusalém. P. 1412-1415

3 Idem, ibidem
}

Revista de Cultura TeOlógICA - v. 15 - N. 59 - ABR/Jun 2007109 
História, religião e religiosidade

Fica consignada nesses textos a idéia de uma nova situação, mas não se identifica a noção de um reino eterno e metafísico.

Em São Paulo, e a partir dele, a concepção será outra - tratava-se, então de projetar a idéia de fim da história para a eternidade, profetizandose a volta de Cristo e a ressurreição dos mortos em uma outra dimensão, a dimensão do eterno, do tempo sem tempo. Por isso, sua insistência na idéia de os homens ressuscitarem como matéria incorruptível, ou seja, não sujeita à transitoriedade da matéria.

"Digo-vos, irmãos: a carne e o sangue não podem herdar o Reino de Deus, nem a corrupção herdar a incorruptibilidade. Eis o que vos dou a conhecer um mistério: nem todos morreremos, mas todos seremos transformados, num instante, num abrir e fechar de olhos, ao som da trombeta final; sim, a trombeta tocará, e os mortos ressurgirão incorruptíveis, e nós seremos transformados. Com efeito é necessário que este ser corruptível revista a incorruptibilidade, e que este ser mortal revista a imortalidade."

Entretanto, seja na concepção veterotestamentária, seja na concepção paulina e neotestamentária, os fundamentos escatológicos do conceito de linearidade já estavam postos - a história da humanidade tem um início e terá um final após um transcurso retilíneo em que os homens deverão buscar o seu aperfeiçoamento moral visando à salvação e a vida eterna.

Não cabe no cristianismo (e em nenhum dos monoteísmos modernos, dada a sua origem comum) a concepção circular, repetitiva da história. Na concepção cristã, segundo a leitura paulina, obrigatoriamente a história terá um final que corresponderá à vitória de Deus sobre o Mal e a Morte.

Por essa razão é que Santo Agostinho irá dizer que

"Os filósofos pagãos introduziram ciclos de tempo em que as mesmas coisas seriam restauradas e repetidas pela ordem da natureza e afirmaram que esses rodopios de idades passadas e futuras prosseguirão incessantemente ... A partir dessa zombaria, são incapazes de por em liberdade a alma imortal, mesmo

4 Idem, p. 2170

110 Revista de Cultura TEOlógICA - v. 15 - N. 59 - ABR/Jun 2007 
depois que ela atingiu a sabedoria, e acreditam que ela está incessantemente caminhando para uma bem - aventurança falsa e incessantemente retornando a uma miséria verdadeira ... É apenas através da sólida doutrina de um curso retilinear que podemos escapar de não sei quantos falsos ciclos descobertos por sábios falsos e enganosos." 5

"Longe de nós repito, acreditar em semelhante insensatez. Cristo morreu uma vez apenas por nossos pecados e ressuscitado dentre os mortos, já não morre e a morte não terá domínio sobre ele. Depois da ressurreição, estaremos eternamente com o Senhor."6

A única morte de Jesus e sua única volta, num futuro incerto, não indicariam a retomada da circularidade da concepção clássica de história, mas confirmam seu caráter retilinear e escatológico - voltando, Cristo porá fim ao tempo histórico e a ressurreição dos homens de modo incorruptíveis indicará, segundo São Paulo, o ingresso no Reino Eterno.

Segundo o conceito cristão, particularmente o católico, a história humana teria se iniciado com Adão e com a segunda volta de Cristo, terá o seu final. A finalidade do transcurso retilinear do processo histórico pode ser interpretada, consoante a doutrina cristã, como a oportunidade oferecida por Deus para que os homens se santifiquem, justificando a sua salvação eterna.

Entretanto, a santificação, isto é, que se justifiquem diante de Deus, é um ato decisivo para a história do homem e depende inteiramente de sua vontade.

A filosofia católica da historia entende que ela é a história da salvação humana. Portanto, primeiro, a história é da humanidade e não de grupos, classes sociais ou de nações, e isso porque o projeto salvífico de Deus se refere a todos os homens e não apenas a alguns deles. Depois, porque a finalidade da história não se refere à temporalidade, mas à eternidade; finalmente, porque o projeto salvífico de Deus não se realizará sem o pleno consentimento da humanidade.

5 AGOSTINHO, Santo, $\boldsymbol{A}$ cidade de Deus. Apud. WHITROW, G.J. O tempo na história, p. 79

6 AGOSTINHO, Santo. A cidade de Deus. V.II, livro $12^{\circ}$, cap. 13 , p. $76 / 77$ 
História, religião e religiosidade

Trata-se, portanto, de uma filosofia que se propõe dialogar com dois universos distintos - um, material, concreto, onde se realiza a história humana; outro, abstrato, idealizado, para onde a história deverá levar os homens. Ser esse final bom ou ruim, é algo que depende inteiramente da vontade humana.

Posta assim a questão, explicita-se que o problema todo radica na vontade e na liberdade humana, atributos que conhecemos pela denominação de livre-arbítrio.

Qual foi o início da história, segundo a doutrina da Igreja? Foi um ato humano ditado pela sua livre opção por não seguir as determinações divinas. Ao escolher não obedecer e adquirir uma sabedoria não prevista por Deus, o homem perdeu a eternidade e entrou na temporalidade. O final da história será o reingresso na eternidade, e se esse reingresso levar o homem ao prêmio ou ao castigo, é algo que novamente está referido ao seu arbítrio. Se ele optar por seguir os ensinamentos da Igreja e a doutrina de Cristo, ele estará salvo; caso contrário ...

Nesse contexto, o ponto nodal é a vontade humana e os atos dela decorrentes. Tudo quanto o homem fez ou fará no concreto da história reflete sua opção - ou ele age conforme os preceitos católicos e isso se reflete no equilíbrio social, ou ele age contra esses preceitos e gera o caos social.

Essa constatação invalida a conviç̧ão de que a Igreja ensina a passividade. Ela ensina, ao contrário, que o homem deve agir fortemente para direcionar sua história para um final feliz, para o reencontro com Deus e não para perdição eterna.

Atribuo essa concepção retilinear a uma origem comum, mas interpretada em duas vertentes distintas. A raiz dessa concepção, entendo ter sido a própria origem do universo, interpretada pelas doutrinas judaica e cristã e pela racionalidade científica.

O relato bíblico contido no Gênesis descreve um processo de evolução do universo a partir de um ato criador de Deus. A seqüência descrita na Bíblia se inicia com a criação da luz e avança até à criação da Humanidade, no sexto dia, passando pela criação do céu e da terra, do dia e da noite, dos mares e dos continentes e dos seres vivos de todas as espécies. (Bíblia de Jerusalém, p. $31-32$ ).

112 ReVISta de Cultura TeOlógica - v. 15 - N. 59 - ABR/Jun 2007 
As pesquisas biológicas, geológicas e da astrofísica confirmam a seqüência bíblica em suas linhas gerais - da luz da explosão primordial (Big Bang) ao ser humano, o mais recente dos animais. Entretanto, nessa teoria científica o processo não teve origem em um ato criacionista, mas em movimentos da própria natureza.

Penso que essas teorias provocaram um desdobramento no próprio desenvolvimento das filosofias da história. Se tudo é um processo evolutivo, desde os movimentos transformadores da geologia até as transformações biológicas, por que a história humana deveria ser diferente? Por que a história humana deveria ser circular se todos os processos são retilineares?

Ao menos essa idéia parecia consolidada até o estabelecimento das modernas teorias da relatividade, e desenvolvidas as pesquisas a partir da teoria do caos e da mecânica quântica. A percepção de que o tempo não é uniformemente distribuído em uma linha contínua; a percepção de que os corpos celestes e a própria matéria estão em constante modificação não seguindo necessariamente uma linha evolutiva contínua e, finalmente, que no plano das nano dimensões os conceitos de espaço, tempo e movimentos devem ser avaliados com outros critérios, provocaram, inevitavelmente, a revisão dos conceitos de evolução progressiva.

Essas novas descobertas e novas teorias, entretanto, ainda não surtiram efeitos consistentes nas filosofias da história. Nesse terreno ainda imperam a idéia de tempo retilinear e a idéia de processo evolutivo, ressalvados alguns autores ligados à Nova História que têm reservas com o conceito de processo evolutivo e progressivo.

Feita essa exceção, percebe-se que a idéia de trajeto retilinear e progressivo está na organização da filosofia da história dos autores que se dispuseram à essa discussão, do lluminismo em diante, com pequenas diferenças entre eles.

Notável a concepção marxista.

Marx propunha uma ruptura radical, revolucionária, com todas as formas anteriores de pensamento histórico e conseguiu, até certo ponto. No entanto, repetiu o já estabelecido no que dizia respeito à idéia de trajeto progressivo e retilinear.

A concepção marxista se fundamentava na tese de que as "idades históricas" se sucederam linearmente, desde as formações pré-capitalistas, passando pelo imperialismo escravista da Antigüidade, pela servidão de 
gleba, no Medievo, chegando ao capitalismo industrial e continuaria seu trajeto inelutável levando a humanidade, em uma marcha ininterrupta, até o reino de paz e justiça na sociedade comunista, e esse processo teria sua dinâmica na contradição dialética entre as classes sociais. Em outros termos, empregando uma palavra muito usada, em especial no Brasil dos anos de 1970, o "fio condutor", a "mola propulsora" da história seria a luta de classes.

Revolucionária, sem dúvida, essa idéia proposta por Marx de que a história se movimenta, não pela ação das elites ou da providência divina, mas pelas contradições internas ao próprio processo da história. Entretanto, não avançou ao reafirmar uma concepção escatológica (uma escatologia materialista, mas nem por isso menos escatológica) e a idéia de avanço retilinear, de marcha progressiva.

Por isso, será muito freqüente, na escrita dos marxistas a idéia de um "fio condutor" a orientar a marcha da humanidade para o pleno progresso, expresso na sociedade sem classes. Por isso, o marxismo,

... 'foi o porta-estandarte do 'progressivismo', a idéia de que existe uma direção para a história e que tipos apropriados de intervenção política podem nos ajudar a demarcá-la e acelerar a jornada. A literatura do socialismo está repleta de falas sobre o 'caminho a ser seguido', a 'marcha para a frente do socialismo', a 'estrada para o socialismo', e assim por diante. As formas mais radicais de pensamento socialista há muito têm argumentado que só existe o movimento para a frente ou para trás: ou a humanidade avança em sua jornada ou provavelmente cairá na barbárie."7

Mesmo quando, no 18 Brumário, analisava e interpretava as derrotas políticas das classes trabalhadoras, Marx reafirmava suas concepções progressivas e escatológicas da história:

“...as revoluções proletárias, como as do século XIX, se criticam constantemente a si próprias, interrompem continuamente seu curso, voltam ao que parecia resolvido para recomeçá-lo outra vez, escarnecem com impiedosa consciência as deficiências,

7 GIDDENS, Anthony. Para além da esquerda e da direita, p. 63

114 ReVISta de Cultura TeOlógica - v. 15 - N. 59 - ABR/Jun 2007 
fraquezas e misérias de seus primeiros esforços, parecem derrubar seu adversário apenas para que este possa retirar da terra novas forças e erguer-se novamente, agigantado, diante delas, recuam constantemente ante a magnitude infinita de seus próprios objetivos até que se cria uma situação que torna impossível qualquer retrocesso..."8

Revolucionário, sim em suas análises, interpretações e propostas, Marx, todavia, era fruto e herdeiro das contribuições intelectuais da Europa dos séculos XVIII e XIX, de modo que sua concepção progressiva da história não foi uma ruptura total em relação ao passado europeu. Encontramos nos pensadores do fim do lluminismo já a mesma concepção evolutiva.

Se em Marx o "fio condutor" da história seria a luta de classes, os iluministas iriam identificar o "fio condutor" aos avanços da ética e da moral com fundamentos nas luzes da ciência, a partir do projeto estabelecido pela natureza para o homem. Em Kant, essa concepção é explicitada na afirmação de que,

"a história humana, no seu conjunto, pode considerar-se como a realização de um plano oculto da natureza, no sentido de estabelecer-se uma constituição politicamente internamente perfeita e, em ordem a este mesmo fim, perfeita também no plano externo, pois esta é a única situação em que a natureza pode desenvolver plenamente na humanidade todas as suas disposições."

Entretanto, em ambos os casos, a história avança, evolui segundo a direção determinada por "um fio condutor" e deve levar o ser humano a algum lugar, em um fim distante - uma concepção escatológica, portanto.

Nos dois trechos citados, além da concepção de história dirigida por um "fio condutor", aparece também a concepção de inexorabilidade - caminhar em direção à perfeição, seja ela a sociedade sem classes ou a sociedade politicamente perfeita da concepção kantiana, é a marca inexorável do processo histórico, um caminho sem volta e sem alternativas. Tal como na concepção religiosa, há um destino para a humanidade, inelutável, passível

8 MARX, K. \& ENGELS, F. 018 Brumário de Luís Bonaparte. p. 206.

9 KANT, I. Idéia de uma história universal de um ponto de vista cosmopolita, p. 37 
de ser retardado pelas contingências políticas conservadoras e reacionárias, mas impossível de ser definitivamente obstado.

As diversas filosofias racionalistas da história do mundo ocidental, ao trabalharem com essas idéias construíram textos que se são diferentes e irreconciliáveis entre si, apresentam o mesmo fundamento - sobre um alicerce semelhante, alicerce comum, herdado das concepções agostinianas, construíram edifícios filosóficos distintos, e sua semelhança fundamental é a crença profética e messiânica no devir imanente ao próprio processo histórico.

As filosofias da história comportam essa crença profética e messiânica, portanto escatológica e teleológica (em um futuro que se espera não muito distante) a humanidade chegará ao fim de sua jornada e encontrará... O que, afinal, encontrará a humanidade no final de seu percurso?

Kant imaginava que o final da trajetória humana seria a construção de uma sociedade moralmente perfeita, pacífica, harmonizada pela racionalidade das leis e pela consciência de que a paz seria preferível à guerra.

Tendo por estabelecido que o mundo moderno deverá chegar inelutavelmente à perfeição, ele assenta todo esse processo na certeza de que a Razão humana produzirá um saber que ilumine os próprios atos do Estado, cujo melhor exemplo muito provavelmente teria sido o Despotismo Esclarecido. Por isso, ele nos diz que

... "à mistura com muitas ilusões e caprichos, vai surgindo, pouco a pouco, a era das Luzes. Estas luzes, porém, e com elas um certo interesse sentimental que o homem esclarecido não pode deixar de ter pelo bem que ele compreende perfeitamente, deve alçar-se progressivamente até os tronos e influenciar os seus próprios princípios de governo"10

Escrevendo na abertura do século XIX, Kant sintetizava a racionalidade moderna do mundo burguês - somente a igualdade e a liberdade garantidas pela lei poderiam dar ao Homem a condição de realizar os projetos que a natureza the preparara, e esse posicionamento sem dúvida era um avanço em relação à sociedade de privilégios e regalias herdadas do medievo e aprofundadas pelo Antigo Regime.

${ }^{10}$ KANT, I. Idéia de uma história universal de um ponto de vista cosmopolita, p. 38

116 ReVISTA de Cultura TEOLÓgICA - v. 15 - N. 59 - ABR/Jun 2007 
Se a profecia kantiana se explicitava no seu texto como promessa de uma sociedade pacífica e harmônica, sua consecução dependeria de um demiurgo - Estado - e de um instrumento - a educação, que aspergiria sobre todos as Luzes da Ciência e promoveria o aperfeiçoamento moral da sociedade humana, conforme também se lê no seguinte texto de Kant

“..embora os governantes do mundo não tenham presentemente dinheiro disponível para as instituições de educação pública, nem para tudo aquilo que em geral represente o melhor do que há no mundo 0 pelo fato de todos os recursos se encontrarem já aplicados de antemão na guerra próxima - no entanto não deixarão certamente de achar vantajosos para eles pelo menos não impedirem os esforços de seu povo nesse sentido, embora fracos e lentos." 11

O posicionamento e a forma de Kant propor e desenvolver a questão não eram seu apanágio. Pode-se citar tantos outros, como Condorcet e Comte. Entretanto, não seria o caso agora de aprofundamento nos outros, exceto Condorcet, considerado o criador da teoria da história como evolução do espírito humano.

Condorcet, considerado por muitos o criador da teoria do progresso do espírito humano, traduz o seu pensamento na seguinte passagem:

"Mas, se considerarmos este mesmo desenvolvimento tal como se manifesta nos indivíduos que coexistem num dado espaço, e se o seguirmos de geração em geração, ele apresenta então o quadro do progresso do espírito humano. Este progresso está submetido às mesmas leis gerais que se observam no desenvolvimento das faculdades dos indivíduos, visto que é o resultado desse desenvolvimento, considerado ao mesmo tempo num grande número de indivíduos reunidos em sociedade. Mas, o que acontece em cada instante é o resultado do que aconteceu em todos os momentos anteriores; e tem, por sua vez, influência sobre o que acontecerá no futuro. Este quadro é portanto histórico, visto que, estando sujeito a perpétuas va-

\footnotetext{
11 Idem, ibidem.
} 
riações, se forma pela observação sucessiva das sociedades humanas nas diferentes épocas que percorreram."12

Os dois pensadores apontados, às vezes identificados sem muita cautela ao "pensamento burguês", circunscreveram o conceito de progresso humano ao âmbito da moral e da ética. Isto é, a humanidade não progrediria apenas porque desenvolveria ciência e tecnologia, mas acima de tudo o progresso se daria pelo controle dos avanços materiais e das relações sociais e políticas por princípios morais e éticos que os direcionariam para o bem, levando àquela sociedade moral e racional de que nos fala José Carlos Reis, acima citado.

$\mathrm{Na}$ leitura de Kant, por exemplo, a sociedade que desenvolvesse plenamente suas potencialidades materiais, mas não as empregasse para a construção da paz, não teria progredido. Mais ainda, conforme o pensador alemão e o francês Condorcet, a perfeição política estaria na conversão de toda sociedade humana em sociedade governada pelos princípios da constituição do Estado de Direito.

Assim, em Kant, a esperança de uma história cosmopolita se firmava na concepção de que o Estado de Direito seria o desdobramento lógico e irrevogável do transcurso da história européia:

“... se partirmos da história grega... se seguirmos de perto sua influência na formação e deformação das instituições políticas do povo romano, que absorveram o estado grego, e depois a influência deste povo romano sobre os Bárbaros, que por sua vez destruíram aquele e assim por diante até nosso tempo; se a conjugarmos episodicamente com a história política de outros povos, cujo conhecimento foi chegando lentamente até nós precisamente através dessas nações mais esclarecidas, descobriremos então uma marcha regular de melhoramento da constituição política de nosso continente (que um dia, provavelmente, virá a dar leis a todos os outros)."13

Para eles, a história seria a história do progresso do espírito humano, um trajeto penoso, difícil, mas retilíneo, que levaria a humanidade da barbárie

12 CONDORCET, N. A. O progresso do espírito humano. P. 63

${ }^{13}$ KANT, I. Idéia de uma história universal de um ponto de vista cosmopolita, p. $39-40$.

118 ReVISTA de Cultura TEOLÓgICA - v. 15 - N. 59 - ABR/Jun 2007 
à plenitude da realização dos projetos da natureza na sociedade pacífica e harmonizada pelo saber, pelas leis, pela igualdade, pela liberdade e pela paz, naquele novo mundo que se construía na Europa e que se deveria tornar cosmopolita, esse mundo que os analistas posteriores denominaram, acertadamente, de capitalista, burguês.

Por isso, Condorcet condensava sua filosofia em esperanças que a "condição futura da espécie humana podem reduzir-se a estes três pontos importantes: a destruição da desigualdade entre as nações; os progressos da igualdade num mesmo povo; e, finalmente, o aperfeiçoamento real do homem." ${ }^{14}$

No universo das filosofias racionalistas, a marca distintiva de Marx está em dois pontos. Primeiro, a idéia de que o reino da paz e da justiça não poderia ser a consolidação universal da sociedade burguesa européia, mas a construção de uma sociedade que Ihe superasse, sendo igualitária, sem classes sociais, em que a proposta de harmonização pela Lei, tão presente em Kant, não teria mais sentido. Segundo, que essa sociedade se constituiria a partir de um paradoxo, isto é, o reino da harmonia se constituiria como término de um processo histórico movimentado pelas contradições.

Ressalvadas essas diferenças, as escolas historiográficas racionalistas européias, que fundamentaram o pensamento historiográfico dos últimos duzentos anos, construíram uma concepção retilinear, progressiva e escatológica da história, portanto não muito diferente da concepção judaico cristã, em particular a construção teórica do catolicismo.

Essa abordagem do problema mantém em aberto o debate sobre a tese da oposição entre a irracionalidade das teorias e filosofias de raiz religiosa e a racionalidade que seria própria e inerente ao pensamento produzido pelas pesquisas e experiências científicas e seus desdobramentos em todas as esferas do saber humano.

É, senão consensual, ao menos muito freqüente na literatura especializada a colocação do problema como ruptura entre racionalismo e irracionalismo, a partir do Renascimento, de modo que, desde então, o ambiente

14 Idem, p. 69

Revista de Cultura TeológIcA - v. 15 - N. 59 - ABR/Jun 2007119 
intelectual europeu pode avançar (progredir?) por ter se libertado das amarras teológicas do cristianismo em sua interpretação católica romana.

A interpretação dessa forma de se propor o problema leva à conclusão de que o saber racional, isto é, o saber elaborado pela especulação filosófica e pela pesquisa científica somente foi possível pela laicização e, no extremo limite, pela constituição do ateísmo na sociedade européia. No inverso da leitura, chega-se à conclusão de que todo pensamento de raiz cristã católica é, por isso mesmo, irracional.

Não se pode ignorar, é verdade, que todo referencial do modo católico de pensar é a vida espiritual pós-morte, o reino celeste. Posto assim, tudo quanto possa significar um obstáculo à ascese humana deve ser afastado, proibido e, em última análise, eliminado, por exemplo, toda pesquisa científica que negue a existência de Deus ou leva a práticas sociais e individuais contrárias à doutrina católica.

Se essa atitude da Igreja Católica Romana é sua tônica, mesmo nos dias atuais, em que não se pode duvidar da prevalência da pesquisa científica e da laicização do Estado no mundo ocidental, mais ainda o era no início dos tempos modernos em que a Igreja de Roma estava no centro da sociedade e era referência para todos os atos humanos. Naqueles prenúncios da modernidade, a aceleração da ciência e a liberalização, ainda que relativa, da filosofia em relação à teologia significaram, sem dúvida, um abalo, uma ameaça ao predomínio político, social e cultural exercido pela Igreja Católica Romana, ameaça que se tornou ainda mais pungente no século XIX.

Posto assim, tudo indica que o maior problema da Igreja Católica naquele momento, bem como em todo desenvolvimento subseqüente da filosofia, da ciência e, finalmente, das teorias e práticas políticas, era a manutenção de sua condição de centro de referência para o mundo ocidental.

O problema maior era que o racionalismo moderno poderia significar no limite extremo da questão, a ruptura do predomínio católico exercido sobre a produção e distribuição do conhecimento no mundo ocidental, desde o Império Carolíngio, e essa situação a Igreja não queria e não podia aceitar ${ }^{15}$.

${ }^{15}$ MANOEL, Ivan A. Igreja e educação feminina: uma face do conservadorismo (1859 - 1919), cap. IV

120 ReVISta de CULtura TeOlógica - V. 15 - N. 59 - ABR/Jun 2007 
Essa ruptura se dera exatamente porque, desde o humanismo renascentista, as novas (ou renovadas) formas de pensar provocaram uma transformação no interior da teoria do conhecimento, estabelecendo que o saber humano não dependia da Revelação Divina - teoria católica do conhecimento - mas era produto mesmo da experiência dos homens no seu contato sensório-motor com o mundo natural. Mais ainda, essa transformação fora correlata a uma redefinição do próprio objeto do conhecimento, colocando, desde então, o Homem como objeto privilegiado da busca do saber. Continuando a tradição teocêntrica e teológica, a doutrina reforçada pelo catolicismo ultramontano não via com bons olhos a preocupação, considerada excessiva, com assuntos demasiadamente humanos que freqüentava o pensamento moderno.

Em outras e mais simples palavras - segundo a doutrina católica, o racionalismo moderno, ao ser excessivamente antropocêntrico, esquecera-se de que o verdadeiro saber é aquele que conduz ao entendimento da doutrina cristã, e por meio dela, o conhecimento de Deus, e aquele que conduz ao avanço material, apesar dos resultados imediatos, é um falso saber.

Transtornando ainda mais o ambiente intelectual, a moderna teoria do conhecimento transbordou os limites das teorias e especulações e penetrou no próprio âmbito da pedagogia, e passou a exigir uma transformação no sistema educacional para torná-lo leigo, público, gratuito e solidamente alicerçado no racionalismo e no empirismo e livre do controle doutrinário da Igreja. A proposta dos pedagogos, filósofos e políticos burgueses, do século $\mathrm{XVIII} \mathrm{em} \mathrm{diante,} \mathrm{continuando} \mathrm{uma} \mathrm{tradição} \mathrm{que} \mathrm{remontava} \mathrm{ao} \mathrm{século} \mathrm{XVI} \mathrm{era,}$ além de substituir a pedagogia católica pela pedagogia moderna, afastar a Igreja de qualquer possibilidade de ingerência administrativa sobre o sistema escolar. Nesse contexto, a secularização do sistema educacional foi a solução encontrada, começando esse processo pela França pós-revolucionária. ${ }^{16}$

Se a doutrina católica condenava o mundo burguês naquilo que se referia à organização sócio-política e naquilo que dizia respeito à vida material, a sua reação diante das novas atitudes filosóficas, teóricas e educacionais foi muito mais vigorosa. Segundo a leitura católica, qual a implicação maior do racionalismo moderno? Conforme essa leitura, ser racionalista e moderno

${ }^{16}$ DEBESSE, M. \& MIALARET, G. Tratado das ciências pedagógicas, v. 02 (História da pedagogia). 
História, religião e religiosidade

implicava, necessariamente, em ser ateu, inimigo de Deus e da Igreja e, no limite extremo, em ser um comunista potencial. ${ }^{17}$

Contudo, cabe perguntar se haviam condições, nos inícios dos tempos modernos, para a constituição de um modo laico, materialista e ateu de pensar. Lucien Febvre pensava que não. Segundo ele, não existiam sequer as palavras para exprimir idéias das ciências e muito menos idéias materialistas:.

"Trata-se do problema de saber que tipo de clareza, de profundidade e finalmente que eficácia poderia ter (...) o pensamento dos homens franceses - que, para especular, não dispunham ainda em sua língua de algumas destas palavras costumeiras, que fluem por si mesmas na nossa pena, tão logo nos pomos a filosofar. Grave constatação: as palavras que se ofereciam a estes homens quando se punham a raciocinar em francês (...) não eram palavras destinadas ao raciocínio, à explicação e à demonstração. Não eram palavras sábias." 18

Penso que ele tinha razão e a leitura de vários filósofos daquele período confirma a sua tese. Bacon, por exemplo, embora tivesse sido um crítico severo da filosofia escolástica católica não desejava uma ruptura abrupta e total com a doutrina cristã. Talvez por isso, no Aforismo LXXXIX, do Novum Organun, se posicionou contra aos que

".parecem temer que a investigação da natureza acabe por subverte ou abalar a autoridade da religião, sobretudo para os ignorantes. Mas estes dois últimos temores parecem-nos saber inteiramente a um instinto próprio dos animais, como se os homens, no recesso de suas mentes e no segredo de suas

\footnotetext{
17 Fazia parte da estratégia do catolicismo ultramontano identificar linearmente o comunismo como resultado do racionalismo e da educação leiga. Abaixo, um exemplo típico dessa atitude, datado de 1874: "A imensa população obreira das grandes cidades européias, alistadas neste momento debaixo das bandeiras do socialismo e do comunismo, lê todos os dias os jornais ímpios, e depois de lê-los é que sai à rua para levantar barricadas e derramar sangue. Em vez de útil, é um imenso perigo para a sociedade essa instrução puramente literária, essa instrução defeituosa e incompleta/Eis, senhores, até onde se chega com educação sem ensino religioso." COSTA, Antônio de Macedo. Discurso na inauguração da Sociedade Promotora da Instrução Pública do Pará, Apud. MANOEL, Ivan A D. Macedo Costa e a laicização do Estado... In, História, N Especial, p.185

${ }^{18}$ FEBVRE, L. O domínio da religião sobre a vida, p. 55
} 
reflexões, desconfiassem e duvidassem da firmeza da religião e do império da fé sobre a razão e, por isso temessem o risco da investigação da verdade da natureza. Contudo, bem consideradas as coisas, a filosofia natural, depois da palavra de Deus, é a melhor medicina contra a superstição e o alimento mais substancioso da fé." 19

Mesmo os filósofos do final do século XVIII e início do XIX não romperam com certa forma religiosa de pensar ou, ao menos, não vislumbraram outros horizontes a não ser aquele que continha uma pitada de religiosidade. Kant, por exemplo, embora questionando a possibilidade de a Razão alcançar a essência das coisas e, portanto, o conhecimento de Deus, não o negou como também não o negou o positivismo comteano que, no avançar de suas especulações acabou por se converter em uma religião. Na esteira das reformas religiosas, os filósofos do período propuseram forma agnósticas, teístas ou não católicas de concepção do sagrado e não o materialismo e o ateísmo absoluto.

Marx, na segunda metade do século XIX, ao elaborar suas teorias, essas sim materialistas e atéias, fez severa e profunda crítica ao agnosticismo, considerando-o um modo acanhado e não corajoso de se enfrentar o mundo moderno cujo limite seria o reformismo pequeno burguês e não um projeto revolucionário. Talvez fosse um ópio pior do que a própria religião, segundo seu entendimento.

Penso que está posto o debate sobre a oposição entre a irracionalidade e a racionalidade no mundo ocidental pós-Renascimento, tendo o seu ápice no século XIX. Nesse debate, tudo leva à constatação de que não se tratou de uma simples oposição filosófica ou teórica entre racional e irracional, aquele, moderno, símbolo e sinônimo do avanço humano, este, retrógrado, representando tudo quanto a moderna ciência e a filosofia livre da teologia estavam a suplantar em um longo embate que poderia perdurar por séculos.

\footnotetext{
${ }^{19}$ BACON, Francis. Novum Organum (verdadeira indicações acerca da intrepretação da natureza), p. 65
} 
História, religião e religiosidade

Antes, tudo indica que se tratava do embate político entre duas racionalidades distintas, irredutíveis entre si, ao menos naquele momento ${ }^{20}$. Eram duas racionalidades distintas, que desenvolveram intelecções incompatíveis entre si sobre o universo, seu movimento e sobre a história humana; uma, criacionista e sacralizadora, a católica, a outra, os diversos matizes do pensamento laico pós-Renascimento, evolucionista e secularizadora.

Giacomo Marramao tem razão, portanto, ao situar o problema como poder e secularização ou quando opõe céu e terra ${ }^{21}$ - era disso que se tratava em última análise, uma disputa pelo poder que estava embutida na busca pela completa secularização da sociedade, indo da pesquisa científica à laicização do Estado e seus serviços, tais como, cemitérios públicos, educação pública, casamento civil, etc. passando por especulações filosóficas livres dos estreitos formalismos escolásticos, como já propusera Bacon, chegando à instauração do poder republicano.

Secularizar o mundo significava muito mais do que a simples laicização, significava trazer o homem para o Século, para a temporalidade, situar sua história nos limites da finitude humana e, nesse novo mundo, secular, finito, materialista, pensavam, o clero católico, herdeiro e defensor da irracionalidade religiosa e das estruturas políticas monárquicas, nada mais teria a dizer nem a fazer, sua função histórica terminara e ele não precisaria mais existir.

Não por acaso o corolário da secularização foi a perseguição anticlerical em parte da Europa e no México, situação que no Brasil foi evitada pelas negociações entre Rui Barbosa e D. Antônio de Macedo Costa, Bispo do Pará, em 1890. ${ }^{22}$

Mas, há uma contradição, um verdadeiro paradoxo nesse contexto representado pela herança cultural do mundo ocidental, particularmente o europeu.

${ }^{20}$ Muitos teóricos, de diversas áreas do conhecimento, têm procurado estabelecer ligações, pontes que possam unir a ciência e a religião. Exemplo disso é o livro, publicado já nos anos 2000, cujo elucidativo título é: Construindo pontes entre a religião e a ciência. Curioso notar que, em um livro com esse título, encontram-se alguns textos de filósofos e cientistas recusando a possibilidade de se construir essa ligação.

21 MARRAMAO, Giacomo. Poder e secularização. São Paulo, Edunesp, 1995. Céu e terra. São Paulo, Edunesp, 1997.

${ }^{22}$ Manoel, Ivan A. D. Antônio de Macedo Costa e Rui Barbosa: a Igreja Católica na ordem republicana brasileira. In, Pós-História (revista de Pós-Graduação em História). Assis, Unesp. V.5, 1997. 
Os fundamentos cristãos, particularmente o católico é uma realidade da qual não se pode fugir, particularmente no que diz respeito aos fundamentos da filosofia da história, comuns aos cristãos e aos racionalistas. A herança da linha evolutiva e escatológica da história, recebida de S. Agostinho, por mais incômoda que pudesse ser, não foi abandonada pelos filósofos e historiadores leigos, que a secularizam, mas não a rejeitaram.

\section{CONCLUSÃO}

Portanto, se é verdade que os avanços científicos na astronomia, na geologia, na biologia, etc. conjugados aos avanços da tecnologia levaram os mitos do cristianismo a um verdadeiro colapso (contra o qual a Igreja do século XIX lutou desesperadamente), não é menos verdadeiro que séculos de predomínio do cristianismo, em sua vertente católica, moldaram em grande parte a forma ocidental de pensar. Essa tensão dialética entre o sagrado e o profano estará presente nas filosofias da história: de um lado, a filosofia cristã - católica que aponta a eternidade como referência, mas sabe que a história se dá na temporalidade, temporalidade que ela rejeita e pretende transformar; de outro, as filosofias leigas, que embora trazendo a história para dentro da temporalidade, sabem que o solo onde vicejam está fertilizado pela herança cristã - católica que rejeitam, e querem a todo custo minimizar.

Quando os autores leigos estabeleceram que a história humana é o trajeto que leva de um ponto $X$ a um ponto $Y$, onde $Y$ é mais avançado do que $X$, estavam usando o mesmo esquema interpretativo empregado pela filosofia cristã - católica, ressalvadas as diferenças impostas pelo racionalismo e mesmo materialismo, tais como sobre as origens do homem e a escatologia materialista, que aponta para um final do processo histórico dentro da temporalidade. Do mesmo modo, quando a filosofia cristã - católica estabeleceu que a temporalidade é o espaço próprio para a realização da história da salvação, estava admitindo, com as filosofias leigas, que a história é concreta, ressalvando-se que estabeleceu uma origem e um fim para o homem e sua história fora da temporalidade.

Parece-me ser esse o centro e o fundamento do problema. Garantir sua existência institucional, sua condição de centro de referência para a humanidade significou, para a Igreja Católica Romana, uma luta, ao longo do período 
que vai do Renascimento, e esmo antes, até fins do século XIX, caracterizada pela desqualificação do oponente - o Racionalismo - considerando-o herege, pernicioso, causador da perdição humana e, quando pode, pela eliminação do oponente - as fogueiras da Inquisição são uma das provas iniludíveis desse processo. Para os racionalistas de todos os matizes, a desqualificação da herança cultural cristã, na sua vertente católica, era estratégia prioritária; no limite, eliminaram o tanto quanto pudera os adversários, o clero católico, em meio a ferozes perseguições anticlericais.

No entanto, o debate foi e é salutar porque propiciou profundas transformações no modo de pensar, no âmbito da ciência e da filosofia, de ambas as partes. Não sé pode esperar, é evidente, que a Igreja de Roma deixe de acreditar em Deus ou destrua sua estrutura hierárquica centrada no papa, o Sumo Pontifex, aquele que comanda o processo de construir pontes de religação entre o sagrado e o profano. Porém, não se pode ignorar que, embora continuando como instituição religiosa, a Igreja Católica Romana, considerada institucionalmente não tem mais a mesma posição inflexível de tempos passados.

Mas, não se pode ignorar, do mesmo modo, que no campo do racionalismo houve também flexibilizações importantes, de modo que o diálogo entre ciência e religião, religião e filosofia racionalista da história está se tornando possível.

Um exemplo elucidativo, vindo do terreno dos católicos é a posição assumida pelos teólogos da libertação, para quem o diálogo entre doutrina social católica e o marxismo era necessário por ser, segundo eles, a única possibilidade de, mantendo a doutrina católica, conseguir realizar a justiça social.

Por essa razão, Frei Beto, no artigo Cristianismo e marxismo, insistia que... "marxistas e cristão têm mais arquétipos em comum do que supõe nossa vã filosofia"... e, mais adiante no mesmo texto, defendia a tese de um dos pontos a unir ambas as posições era a luta comum pela justiça:

"Um deles é a utopia da felicidade humana no futuro histórico, esperança que se faz mística na prática de inúmeros militantes que não temem o sacrifício da própria vida. Marx chama essa plenitude de reino da liberdade e, os cristãos, de reino de Deus. Ora, nada na política ou na história garante a realização dessa

126 ReVISTA de Cultura TEOLÓgICA - v. 15 - N. 59 - ABR/Jun 2007 
meta, como também a salvação esperada pelos cristãos não tem explicação histórica, é dom de Deus. Mas há, no mais profundo de nosso ser, o desejo comum de inúmeros marxistas e cristãos de que a humanidade elimine todas as barreiras e contradições que separam os homens.E a esperança incontida de que o futuro será como a mesa posta em torno da qual, irmanados, todos haverão de partilhar a fartura do pão e a alegria do vinho"23

A proposta de diálogo está posta há muito tempo. O tempo dirá se houve resultados.

\section{BIBLIOGRAFIA}

AGOSTINHO (Santo), Bispo de Hipona. A cidade de Deus (contra os pagãos). Petrópolis, Vozes, São Paulo, Federação Agostiniana Brasileira, 1990, 2 v.

BACON, Francis. Novum Organum (verdadeira indicações acerca da intrepretação da natureza). São Paulo, Abril S.A. 1973. (Coleção Os Pensadores, v. XIII).

BIGNOTTO, Newton. O círculo e a linha. In, NOVAIS, Adauto (org). Tempo e história. São Paulo, Cia das Letras/Secretaria Municipal da Cultura, 1992.

COMTE, Auguste. Catecismo positivista. In, Comte, A Seleção de textos. São Paulo, Abril Cultural, 1983 (Os Pensadores).

CONDORCET, Nicolas A, O progresso do espírito humano. In, GARDINER, Patrick L. Teorias da História. Lisboa, Calouste-Gulbenkian, 1969.

DONOSO-CORTÉS, J. Bosquejos Historicos. In, JURETSCHKE, J. (org). Obras completas de Donoso-Cortés. Madrid, Editorial Católica, 1946, T. II.

DONOSO-CORTÉS, J. Ensayo sobe el catolicismo, el liberalismo y el socialismo. In, idem, ibidem.

EDIÇÕES PAULINAS. A Bíblia de Jerusalém. São Paulo, Ed. Paulinas, 1992. FEBVRE, Lucien. O domínio da religião sobre a vida. In, MOTA, Carlos G. (org). L. Febvre: história. São Paulo, Ática, 1978.

FREI BETO, Cristianismo e Marxismo. In, LÖWY, Nichael (org.) O marxismo na América Latina: uma ontologia de 1909 aos dias atuais. São Paulo: Editora Fundação Perseu Abramo, 1999.

ENGELS, F. Feuerbach e o fim da filosofia clássica alemã. In, MARX, K. \&

${ }^{23}$ FREI BETO, Cristianismo e marxismo, 1999, p. 485. 
ENGELS, F. Textos. São Paulo, Edições Sociais, 1977, v. I.

GIDDENS, Anthony. Para além da esquerda e da direita. São Paulo, Editora Unesp, 1996.

GURIÊVITCH, Aaron. A síntese histórica e a Escola dos Anais. São Paulo, Ed. Perspectivs, 2003.

KANT, Immanuel. Idéia de uma história universal de um ponto de vista cosmopolita. In, Gardiner, P.L. Op.Cit.

LENINE, V.I. Que fazer? In, Obras escolhidas. São Paulo, Alfa-Omega, 1979, V. I.

LÖWITH, Karl. El sentido de la historia (implicaciones teológicas de la filosofia de la historia). Madrid, Aguillar, 1958.

MARX, K. \& ENGELS, F. Textos. São Paulo, Edições Sociais, s.d. v. III.

MARX, K. \& ENGELS, F. Manifesto do Partido Comunista. In, MARX, K. \& ENGELS, F. Textos. São Paulo, Edições Sociais, s.d. v. III.

MARX, K. \& ENGELS, F. O 18 Brumário de Luís Bonaparte. In, MARX, K. \& ENGELS, F. Textos. São Paulo, Edições Sociais, s.d. v. III.

MANOEL, Ivan Ap. O pêndulo da história: tempo e eternidade no pensamento católico. Maringá, EDUEM, 2004.

MANOEL, Ivan Ap. \& FREITAS, Nainora M. B. de. História das religiões: desafios teóricos, filosóficos e metodológicos. São Paulo, Paulinas/ABHR, 2006.

PIO X, Papa. Sobre as doutrinas modernistas: encíclica Pascendi Domini Gregis e decreto Lamentabili. Petrópolis, Vozes, 1948.

VORGRIMLER, Herbert. Escatologia/Juízo. In, EICHER, Peter. Dicionário de conceitos fundamentais de Teologia. São Paulo, Paulus, 1993, p. 229 $-235$.

WHITROW, G.J. O tempo na história. Rio, Jorge Zahar, 1993.

Prof. Dr. Ivan Ap. Manoel

Departamento de História, FHDSS - Unesp, Campus de Franca.

<ivan@franca.unesp.br>

128 ReVISta de Cultura TeOlógIcA - v. 15 - N. 59 - ABR/Jun 2007 